\title{
EKSPERIMENTASI MODEL PEMBELAJARAN KOOPERATIF TIPE THINK PAIR SHARE TERHADAP PRESTASI BELAJAR DITINJAU DARI KECERDASAN LOGIKA MATEMATIKA
}

\author{
Desi Tri Utami ${ }^{1}$, Nuning Melianingsih ${ }^{2}$ \\ Program Studi Mesin Otomotif, Politeknik Pratama Mulia Surakarta ${ }^{1}$ \\ Program Studi Manajemen Informatika, Politeknik Pratama Mulia Surakarta ${ }^{2}$ \\ Email : desitriutami0812@gmail.com
}

\begin{abstract}
Abstrak
Penelitian ini bertujuan untuk mengetahui pengaruh model pembelajaran kooperatif tipe Think Pair Share (TPS) terhadap prestasi belajar matematika siswa ditinjau dari kecerdasan logika matematika. Penelitian ini merupakan penelitian eksperimental semu. Populasi penelitian ini adalah seluruh siswa kelas VII SMP Negeri di Kabupaten Sukoharjo. Teknik analisis data yang digunakan adalah uji analisis variansi dua jalan dengan sel tak sama. Kesimpulan penelitian ini, yaitu: (1) model pembelajaran TPS menghasilkan prestasi belajar yang lebih baik dari model pembelajaran konvensional; (2) tidak ada perbedaan prestasi belajar matematika antara siswa dengan kecerdasan logika matematika tinggi dan sedang, serta siswa dengan kecerdasan logika matematika sedang dan rendah; siswa dengan kecerdasan logika matematika tinggi memberikan prestasi belajar matematika yang lebih baik daripada siswa dengan kecerdasan logika matematika rendah; (3) pada kelompok siswa yang dikenai model pembelajaran TPS dan konvensional, siswa dengan kecerdasan logika matematika tinggi, sedang, dan rendah menghasilkan prestasi belajar yang sama baiknya; (4) pada kelompok siswa dengan kecerdasan logika matematika tinggi dan rendah, penggunaan model pembelajaran TPS dan konvensional menghasilkan prestasi belajar yang sama baiknya; pada kelompok siswa dengan kecerdasan logika matematika sedang, model pembelajaran TPS menghasilkan prestasi belajar yang lebih baik dari model pembelajaran konvensional.
\end{abstract}

Kata Kunci : Think Pair Share, Prestasi Belajar, Kecerdasan Logika Matematika

\begin{abstract}
This research aims to prove the effect of the Think Pair Share (TPS) cooperative learning model on students' mathematics learning achievement in terms of logical-mathematical intelligence. The research is a quasi-experimental study. The population of the research is all seventh grade students of State Junior High Schools in Sukoharjo Regency. The data analysis technique used is a two-way analysis of variance with unequal cells. The conclusions of the research are: (1) TPS learning model produces learning achievement better than conventional learning model; (2) there is no difference in mathematics learning achievement between students with high and average logical-mathematical intelligence, and students with average and low logical-mathematical intelligence; students with high logical-mathematical intelligence have better mathematics learning achievement than those with low logical-mathematical intelligence; (3) in the group of students with high, average, and low logicalmathematical intelligence, the use of conventional and TPS learning models produces equally good learning achievements; (4) in the group of students with high and low logical-mathematical intelligence, the use of conventional and TPS learning models produces equally good learning achievements; in the group of students with average logical-mathematical intelligence, the TPS learning model produces learning achievements better than conventional learning model.
\end{abstract} Keywords: Think Pair Share, Learning Achievement, Logical-Mathematical Intelligence

\section{PENDAHULUAN}

Matematika termasuk ilmu yang cukup menentukan dalam perkembangan ilmu pengetahuan dan teknologi. Masalah klasik yang sering ditemukan dalam pembelajaran matematika yaitu prestasi belajar siswa yang masih rendah. Menurut data dari Badan Standar Nasional Pendidikan rata-rata nilai ujian nasional matematika pada tahun pelajaran 
2016/2017 untuk SMP/MTs di Kabupaten Sukoharjo hanya sebesar 48,65 dan masih di bawah rata-rata nilai ujian nasional yang sebesar 50,31. Penguasaan siswa dalam materi aljabar di Kabupaten Sukoharjo masih tergolong rendah. Salah satu bagian dari materi aljabar yaitu persamaan dan pertidaksamaan linier satu variabel. Daya serap pada indikator materi persamaan dan pertidaksamaan linier satu variabel pada tahun pelajaran 2012/2013 hanya sebesar $51,23 \%$, tahun 2013/2014 sebesar 50,62\%, dan tahun 2014/2015 sebesar 43,90\%. Daya serap pada materi aljabar pada tahun 2015/2016 sebesar 49,39\% dan tahun 2016/2017 sebesar 48,64\%. Data tersebut menunjukkan bahwa dari tahun ke tahun siswa masih kesulitan dalam mempelajari materi aljabar.

Prestasi belajar matematika siswa dipengaruhi oleh faktor internal dan faktor eksternal. Faktor internal adalah faktor yang berasal dari dalam diri siswa sendiri, seperti motivasi, kecerdasan emosional, kecerdasan logika matematika, dan lainlain. Sedangkan, faktor eksternal adalah faktor yang berasal dari luar diri siswa, seperti sarana dan prasarana, lingkungan, guru, kurikulum, dan metode mengajar [1]. Keberhasilan dalam pembelajaran matematika dipengaruhi oleh beberapa faktor, salah satunya yaitu pemilihan model pembelajaran yang akan digunakan. Pemilihan model pembelajaran yang tepat akan memberikan dampak positif terhadap prestasi belajar siswa. Suatu model pembelajaran hendaknya dapat menimbulkan interaksi timbal balik antara guru dengan siswa dan siswa dengan siswa lainnya yang saling menguntungkan sehingga tercapai tujuan pembelajaran.

Model pembelajaran kooperatif merupakan salah satu model pembelajaran yang dapat membuat siswa belajar lebih aktif, mampu berinteraksi dengan siswa lain, berpikir kritis, dan mengembangkan kecerdasan yang dimilikinya. Salah satu model pembelajaran kooperatif yaitu TPS yang dapat memberi siswa waktu untuk berpikir, merespon, dan saling membantu [2]. Faktor lain yang berpengaruh terhadap prestasi belajar adalah tingkat kecerdasan yang dimiliki oleh siswa. Kecerdasan logika matematika memuat kemampuan seseorang dalam berpikir secara induktif dan deduktif, kemampuan berpikir menurut aturan logika, memahami dan menganalisis pola-pola angka, serta memecahkan masalah dengan menggunakan kemampuan berpikir. [3].

Penelitian ini bertujuan untuk mengetahui: (1) manakah yang menghasilkan prestasi belajar lebih baik antara pembelajaran matematika yang menggunakan model pembelajaran kooperatif tipe TPS atau model pembelajaran konvensional; (2) manakah yang mempunyai prestasi belajar lebih baik antara siswa yang memiliki kecerdasan logika matematika tinggi, sedang, atau rendah; (3) pada masingmasing kategori model pembelajaran, manakah yang mempunyai prestasi belajar yang lebih baik, siswa yang memiliki kecerdasan logika matematika tinggi, sedang, atau rendah; (4) pada masingmasing kategori kecerdasan logika matematika, manakah yang menghasilkan prestasi belajar yang lebih baik model pembelajaran kooperatif tipe TPS atau model pembelajaran konvensional.

\section{METODE}

Populasi dalam penelitian ini yaitu seluruh siswa kelas VII SMP Negeri di Kabupaten Sukoharjo, dan sampelnya diambil dengan teknik cluster random sampling. Penelitian dilakukan di SMP Negeri 1 Bendosari dan SMP Negeri 3 Polokarto yang masingmasing diambil dua kelompok. Sampel dalam penelitian ini berjumlah 121 siswa yang terdiri dari 60 siswa pada kelompok eksperimen dan 61 siswa pada kelompok kontrol. Penelitian ini termasuk penelitian 
eksperimental semu dengan rancangan faktorial $2 \times 3$ yang digambarkan pada Tabel 1 berikut.

Tabel 1. Rancangan Faktorial

\begin{tabular}{cccc}
\hline \multirow{2}{*}{ Model } & \multicolumn{3}{c}{ Kecerdasan Logika } \\
Membelajaran (A) & Tinggi & Sedang & Rendah \\
& $\left(b_{1}\right)$ & $\left(b_{2}\right)$ & $\left(b_{3}\right)$ \\
\hline TPS $\left(a_{1}\right)$ & $(a b)_{11}$ & $(a b)_{12}$ & $(a b)_{13}$ \\
Konvensional $\left(a_{2}\right)$ & $(a b)_{21}$ & $(a b)_{22}$ & $(a b)_{23}$ \\
\hline
\end{tabular}

Keterangan:

A : Model pembelajaran

B : Kecerdasan logika matematika

$a_{1}$ : Model pembelajaran kooperatif tipe TPS

$a_{2}$ : Model pembelajaran konvensional

$b_{1}$ : Kecerdasan logika matematika tinggi

$b_{2}$ : Kecerdasan logika matematika sedang

$b_{3}$ : Kecerdasan logika matematika rendah

$(a b)_{11}$ : Prestasi belajar matematika siswa yang dikenai model pembelajaran kooperatif tipe TPS dan memiliki kecerdasan logika matematika tinggi.

$(a b)_{12}$ : Prestasi belajar matematika siswa yang dikenai model pembelajaran kooperatif tipe TPS dan memiliki kecerdasan logika matematika sedang.

$(a b)_{13}$ : Prestasi belajar matematika siswa yang dikenai model pembelajaran kooperatif tipe TPS dan memiliki kecerdasan logika matematika rendah.

$(a b)_{21}$ : Prestasi belajar matematika siswa yang dikenai model pembelajaran konvensional dan memiliki kecerdasan logika matematika tinggi.

$(a b)_{22}$ : Prestasi belajar matematika siswa yang dikenai model pembelajaran konvensional dan memiliki kecerdasan logika matematika sedang.

$(a b)_{23}$ : Prestasi belajar matematika siswa yang dikenai model pembelajaran konvensional dan memiliki kecerdasan logika matematika rendah.
Dalam penelitian ini terdapat satu variabel terikat yaitu prestasi belajar matematika, serta dua variabel bebas yaitu model pembelajaran dan kecerdasan logika matematika siswa. Teknik pengumpulan data menggunakan metode dokumentasi dan metode tes. Metode dokumentasi digunakan untuk mengumpulkan data kemampuan awal siswa, metode tes digunakan untuk mengumpulkan data prestasi belajar dan kecerdasan logika matematika. Instrumen yang digunakan dalam penelitian ini berupa tes objektif berbentuk pilihan ganda pada materi persamaan dan pertidaksamaan linear satu variabel dan tes kecerdasan logika matematika untuk membedakan kecerdasan logika matematika siswa dalam kategori tinggi, sedang, atau rendah.

Uji coba instrumen tes kecerdasan logika matematika dan tes prestasi belajar matematika dilakukan di SMP Negeri 1 Bendosari pada kelas VII-C dan SMP Negeri 3 Polokarto pada kelas VII-A dengan jumlah responden sebanyak 61 siswa.

Teknik analisis data yang digunakan dalam penelitian ini meliputi uji prasyarat analisis dan uji hipotesis. Uji prasyarat analisis yaitu uji normalitas menggunakan uji Lilliefors, uji homogenitas menggunakan uji Bartlett, dan uji keseimbangan menggunakan anava satu jalan dengan sel tak sama. Uji hipotesisnya menggunakan uji anava dua jalan dengan sel tak sama yang dilanjutkan dengan uji komparasi ganda dengan metode Scheffe jika hipotesis nol ditolak.

\section{HASIL DAN PEMBAHASAN}

Hasil dari uji prasyarat pada data kemampuan awal siswa menunjukkan bahwa semua sampel berasal dari populasi yang berdistribusi normal dan mempunyai variansi yang sama. Hal ini ditunjukkan pada hasil perhitungan uji normalitas data 
kemampuan awal. Pada data kemampuan awal, hasil perhitungan uji normalitas pada kelompok model pembelajaran kooperatif tipe TPS yaitu $L_{o b s}=0,0992$ yang lebih kecil dari $L_{\text {tabel }}=0,1144$ dan pada model pembelajaran konvensional yaitu $L_{o b s}=$ 0,0993 yang lebih kecil dari $L_{\text {tabel }}=0,1341$. Sehingga, semua sampel berasal dari populasi yang berdistribusi normal. Hasil perhitungan uji homogenitas pada kelompok model pembelajaran kooperatif tipe TPS dan konvensional diperoleh $\chi^{2}$ obs $=0,2381$ dengan $\chi_{\text {tabel }}^{2}=3,8410$. Sehingga semua sampel berasal dari populasi yang homogen. Pada data kemampuan awal juga dilakukan uji keseimbangan antar kelompok model pembelajaran. Berdasarkan hasil uji keseimbangan, diperoleh $F_{o b s}=3,4940$ dengan $F_{0,05 ; 1 ; 119}=$ 4,00 . Sehingga, sampel berasal dari populasi untuk kelompok model pembelajaran kooperatif tipe TPS dan konvensional dalam keadaan seimbang.

Deskripsi data prestasi prestasi belajar matematika siswa dengan model pembelajaran kooperatif tipe TPS. Jumlah siswa sebanyak 60 siswa dengan rerata marginal 53,7333. Kelompok ini terdiri dari 30 siswa yang memiliki kecerdasan logika matematika tinggi dengan nilai ratarata 55,6000, 12 siswa yang memiliki kecerdasan logika matematika sedang dengan nilai rata-rata 58,3333, dan 18 siswa yang memiliki kecerdasan logika matematika rendah dengan nilai rata-rata 47,5556 .

Deskripsi data prestasi prestasi belajar matematika siswa dengan model pembelajaran konvensional. Jumlah siswa sebanyak 61 siswa dengan rerata marginal 46,6885. Kelompok ini terdiri dari 16 siswa yang memiliki kecerdasan logika matematika tinggi dengan nilai rata-rata $54,2500,22$ siswa yang memiliki kecerdasan logika matematika sedang dengan nilai rata-rata 44,0000 , dan 23 siswa yang memiliki kecerdasan logika matematika rendah dengan nilai rata-rata 44,0000.

Rerata marginal untuk siswa yang memiliki kecerdasan logika matematika tinggi sebesar 54,9250, siswa yang memiliki kecerdasan logika matematika sedang sebesar 51,1667, siswa yang memiliki kecerdasan logika matematika rendah sebesar 45,7778.

Hasil uji prasyarat pada data prestasi belajar matematika siswa menunjukkan bahwa semua sampel berasal dari populasi yang berdistribusi normal dan mempunyai variansi yang sama. Hal ini ditunjukkan pada hasil perhitungan uji normalitas data prestasi belajar matematika siswa. Hasil uji normalitas kelompok model pembelajaran kooperatif tipe TPS, konvensional, dan kelompok kecerdasan logika matematika tinggi, sedang, dan rendah. Untuk kelompok yang dikenai model pembelajaran kooperatif tipe TPS diperoleh $L_{o b s}=0,0879$ yang lebih kecil dari $L_{\text {tabel }}=0,1144$. Untuk kelompok model pembelajaran konvensional diperoleh $L_{o b s}=0,0932$ yang lebih kecil dari $L_{\text {tabel }}=0,1134$. Untuk kelompok siswa dengan kecerdasan logika matematika tinggi diperoleh $L_{o b s}=0,1231$ yang lebih kecil dari $L_{\text {tabel }}=0,1306$. Untuk kelompok siswa dengan kecerdasan logika matematika sedang diperoleh $L_{o b s}=0,1179$ yang lebih kecil dari $L_{\text {tabel }}=0,1519$. Untuk kelompok siswa dengan kecerdasan logika matematika rendah diperoleh $L_{o b s}=0,0867$ yang lebih kecil dari $L_{\text {tabel }}=0,1384$. Hal ini menunjukkan semua sampel pada penelitian ini berasal dari populasi yang berdistribusi normal.

Hasil perhitungan uji homogenitas pada kelompok model pembelajaran kooperatif tipe TPS dan konvensional, serta kelompok kecerdasan logika matematika tinggi, sedang, dan rendah menunjukkan bahwa 
sampel berasal dari populasi yang mempunyai variansi sama.. Untuk kelompok model pembelajaran kooperatif tipe TPS dan konvensional diperoleh $\chi^{2}$ obs $=1,0621$ yang lebih kecil dari $\chi^{2}$ tabel $=$ 3,8410 . Untuk kelompok siswa dengan kecerdasan logika matematika tinggi, sedang, dan rendah diperoleh $\chi^{2}$ obs $=$ 5,8919 yang lebih kecil dari $\chi^{2}$ tabel $=$ 5,9910. Hal ini menunjukkan bahwa sampel berasal dari populasi yang mempunyai variansi sama.

Selanjutnya dilakukan uji analisis variansi dua jalan dengan sel tak sama. Rangkuman uji analisis variansi disajikan pada Tabel 2 berikut ini.

Tabel 2. Rangkuman Analisis Variansi Dua Jalan

\begin{tabular}{lccccc}
\hline \multicolumn{1}{c}{ Sumber } & JK & dk & RK & $\mathbf{F}_{\text {obs }}$ & $\mathbf{F}_{\text {tabel }}$ \\
\hline $\begin{array}{l}\text { Model } \\
\text { Pembelaja- } \\
\text { ran (A) }\end{array}$ & 1143,61 & 1 & 1143,61 & 8,62 & 4,00 \\
$\begin{array}{l}\text { Kecerdasan } \\
\text { Logika }\end{array}$ & & & & & \\
$\begin{array}{l}\text { Matematika } \\
\text { (B) }\end{array}$ & 1567,56 & 2 & 783,78 & 5,91 & 3,15 \\
$\begin{array}{l}\text { Interaksi } \\
\text { (AB) }\end{array}$ & 894,75 & 2 & 447,38 & 3,27 & 3,15 \\
$\begin{array}{l}\text { Galat } \\
\text { Total }\end{array}$ & 15253,31 & 115 & 132,64 & - & - \\
\hline
\end{tabular}

Kesimpulan analisis variansi dua jalan dengan sel tak sama berdasarkan tabel di atas, yaitu: (1) pada efek utama antar baris (A), ada interaksi antara model pembelajaran (model pembelajaran kooperatif tipe TPS dan konvensional) terhadap prestasi belajar matematika; (2) pada efek utama antar kolom (B), menunjukkan ada interaksi antara kecerdasan logika matematika siswa (kecerdasan logika matematika tinggi, sedang, dan rendah) terhadap prestasi belajar matematika; (3) pada efek interaksi (C), ada interaksi antara model pembelajaran dan kecerdasan logika matematika siswa terhadap prestasi belajar matematika siswa.
Berdasarkan hasil perhitungan anava dua jalan diperoleh bahwa $\mathrm{H}_{0 \mathrm{~A}}$ ditolak, sehingga perlu dilakukan uji komparasi ganda antar baris dengan metode Scheffe. Analisis data yang dilakukan terhadap $\mu_{1}$. vs $\mu_{2}$. menghasilkan nilai $F_{o b s}=11,3180$ lebih besar dari $\quad F_{\text {tabel }}=4,00$. Sehingga, model pembelajaran kooperatif tipe TPS menghasilkan prestasi belajar matematika yang lebih baik dari model pembelajaran konvensional. Hal ini juga didukung penelitian yang dilakukan oleh peneliti lain. Siswa yang diberi perlakuan dengan model pembelajaran kooperatif tipe TPS mempunyai prestasi belajar dan self-esteem yang lebih baik dibanding model pembelajaran konvensional [4]. Hasil belajar matematika siswa dengan motivasi belajar tinggi dan rendah yang diberi perlakuan model pembelajaran kooperatif tipe TPS lebih baik dari pada NHT [5].

Berdasarkan hasil perhitungan anava dua jalan diperoleh bahwa $\mathrm{H}_{0 \mathrm{~B}}$ ditolak, sehingga perlu dilakukan uji komparasi ganda antar kolom dengan metode Scheffe. Analisis data yang dilakukan terhadap $\mu_{.1}$ dan $\mu_{22}$ menghasilkan nilai $F_{o b s}=2,0820$ lebih kecil dari $F_{\text {tabel }}=6,3$. Hal ini menunjukkan bahwa tidak ada perbedaan prestasi belajar matematika siswa dengan kecerdasan logika matematika tinggi dan siswa dengan kecerdasan logika matematika sedang. Analisis data yang dilakukan terhadap $\mu_{1 .}$ dan $\mu_{.3}$ menghasilkan nilai $F_{o b s}=13,6752$ lebih besar dari $F_{\text {tabel }}=$ 6,3 . Hal ini menunjukkan bahwa ada perbedaan prestasi belajar matematika siswa dengan kecerdasan logika matematika tinggi dan siswa dengan kecerdasan logika matematika rendah. Berdasarkan rerata marginal diperoleh rerata kecerdasan logika matematika tinggi sebesar 54,9250 dan kecerdasan kecerdasan logika matematika rendah sebesar 46,7541. Dapat disimpulkan bahwa siswa dengan kecerdasan logika matematika tinggi memberikan prestasi 
belajar matematika yang lebih baik daripada siswa dengan kecerdasan logika matematika rendah. Analisis data yang dilakukan terhadap $\mu_{.2}$ dan $\mu_{.3}$ menghasilkan nilai $F_{o b s}=4,0694$ lebih kecil dari $\mathrm{F}_{\text {tabel }}=$ 6,3 . Hal ini menunjukkan bahwa tidak ada perbedaan prestasi belajar matematika siswa dengan kecerdasan logika matematika sedang dan siswa dengan kecerdasan logika matematika rendah. Hal ini didukung penelitian yang dilakukan oleh peneliti lain. Siswa dengan kecerdasan logika matematika tinggi lebih aktif dalam pembelajaran di kelas daripada siswa dengan kecerdasan logika matematika sedang maupun rendah, sehingga prestasi belajar matematika siswa dengan kecerdasan logika matematika tinggi lebih baik daripada siswa dengan kecerdasan logika matematika sedang maupun rendah [6].

Berdasarkan anava dua jalan diperoleh bahwa $\mathrm{H}_{0 \mathrm{AB}}$ ditolak, sehingga perlu dilakukan uji komparasi rerata antar sel pada baris yang sama. Analisis data yang dilakukan terhadap $\mu_{11}$ dan $\mu_{12}$ menghasilkan nilai $F_{o b s}=0,4828$ lebih kecil dari $F_{\text {tabel }}=11,85$. Analisis data yang dilakukan terhadap $\mu_{12}$ dan $\mu_{13}$ menghasilkan nilai $F_{o b s}=6,3056$ lebih kecil dari $F_{\text {tabel }}=11,85$. Analisis data yang dilakukan terhadap $\mu_{11}$ dan $\mu_{13}$ menghasilkan nilai $F_{o b s}=5,4888$ lebih kecil dari $F_{\text {tabel }}=11,85$. Analisis data yang dilakukan terhadap $\mu_{21}$ dan $\mu_{22}$ menghasilkan nilai $F_{o b s}=7,3374$ lebih kecil dari $F_{\text {tabel }}=11,85$. Analisis data yang dilakukan terhadap $\mu_{22}$ dan $\mu_{23}$ menghasilkan nilai $F_{o b s}=0,0000$ lebih kecil dari $F_{\text {tabel }}=11,85$. Analisis data yang dilakukan terhadap $\mu_{21}$ dan $\mu_{23}$ menghasilkan nilai $F_{o b s}=7,4742$ lebih kecil dari $F_{\text {tabel }}=11,85$. Hal ini menunjukkan bahwa pada kelas yang dikenai model pembelajaran kooperatif tipe TPS dan konvensional, prestasi belajar matematika siswa dengan kecerdasan logika matematika tinggi sama baiknya dengan siswa dengan kecerdasan logika matematika sedang dan rendah.

Berdasarkan anava dua jalan diperoleh bahwa $\mathrm{H}_{0 \mathrm{AB}}$ ditolak, sehingga perlu dilakukan uji komparasi rerata antar sel pada kolom yang sama. Analisis data yang dilakukan terhadap $\mu_{11}$ dan $\mu_{21}$ menghasilkan nilai $F_{o b s}=0,1434$ lebih kecil dari $F_{\text {tabel }}=11,85$. Hal ini menunjukkan pada siswa dengan kecerdasan logika matematika tinggi tidak terdapat perbedaan prestasi belajar matematika antara siswa yang dikenai model pembelajaran kooperatif tipe TPS dan siswa yang dikenai model pembelajaran konvensional. Analisis data yang dilakukan terhadap $\mu_{12}$ dan $\mu_{22}$ menghasilkan nilai $F_{o b s}=12,0269$ lebih besar dari $F_{\text {tabel }}=11,85$. Hal ini menunjukkan terdapat perbedaan prestasi belajar matematika antara siswa dengan kecerdasan logika matematika sedang pada siswa yang dikenai model pembelajaran kooperatif tipe TPS dan siswa yang dikenai model pembelajaran konvensional. Berdasarkan rerata marginal diperoleh rerata siswa dengan kecerdasan logika matematika sedang yang dikenai model pembelajaran kooperatif tipe TPS sebesar 58,3333 dan untuk siswa dengan kecerdasan logika matematika sedang yang dikenai model pembelajaran konvensional sebesar 44,000. Dapat disimpulkan bahwa siswa dengan kecerdasan logika matematika sedang pada kelas yang dikenai model pembelajaran kooperatif tipe TPS menghasilkan prestasi belajar matematika yang lebih baik daripada kelas yang dikenai model pembelajaran konvensional. Analisis data yang dilakukan terhadap $\mu_{13}$ dan $\mu_{23}$ menghasilkan nilai $F_{o b s}$ $=0,9624$ lebih kecil dari $F_{\text {tabel }}=11,85$. Hal ini menunjukkan pada siswa dengan kecerdasan logika matematika rendah tidak terdapat perbedaan prestasi belajar matematika antara siswa yang dikenai 
model pembelajaran kooperatif tipe TPS dan siswa yang dikenai model pembelajaran konvensional.

\section{SIMPULAN}

Berdasarkan hasil analisis data dan pembahasan yang telah dilakukan, maka dapat disimpulkan hasil penelitian sebagai berikut. (1) Pembelajaran dengan menggunakan model pembelajaran kooperatif tipe TPS menghasilkan prestasi belajar yang lebih baik dibandingkan dengan model pembelajaran konvensional. (2) Tidak ada perbedaan prestasi belajar matematika siswa dengan kecerdasan logika matematika tinggi dan siswa dengan kecerdasan logika matematika sedang. Siswa dengan kecerdasan logika matematika tinggi memberikan prestasi belajar matematika yang lebih baik daripada siswa dengan kecerdasan logika matematika rendah. Tidak ada perbedaan prestasi belajar matematika siswa dengan kecerdasan logika matematika sedang dan siswa dengan kecerdasan logika matematika rendah. (3) Pada kelompok siswa yang dikenai model pembelajaran kooperatif tipe TPS, siswa dengan kecerdasan logika matematika tinggi, sedang, dan rendah menghasilkan prestasi belajar yang sama baiknya. Pada kelompok siswa yang dikenai model pembelajaran konvensional, siswa dengan kecerdasan logika matematika tinggi, sedang, dan rendah menghasilkan prestasi belajar yang sama baiknya. (4) Pada kelompok siswa dengan kecerdasan logika matematika tinggi dan rendah penggunaan model pembelajaran kooperatif TPS dan model pembelajaran konvensional menghasilkan prestasi belajar yang sama baiknya. Pada kelompok siswa dengan kecerdasan logika matematika sedang, model pembelajaran kooperatif tipe TPS menghasilkan prestasi belajar lebih baik dari model pembelajaran konvensional.

\section{DAFTAR PUSTAKA}

[1] H. Suhendri. "Pengaruh Kecerdasan Matematis-Logis dan Kemandirian Belajar Terhadap Hasil Belajar Matematika". Jurnal Formatif, vol. 1, no. 1, pp. 29-39, 2011.

[2] Trianto. "Mendesain Model Pembelajaran Inovatif-Progresif: Konsep, Landasan, dan Impementasinya pada Kurikulum Tingkat Satuan Pendidikan (KTSP)". Jakarta : Kencana Media Group, 2010.

[3] P. A. Prawira "Psikologi Pendidikan dalam Perspektif Baru”. Yogyakarta: Ar-ruzz Media, 2012.

[4] M. M. Chianson, I. E. O'kwu, and M. S. Kurumeh. "Effect Of Think-PairShare Strategy on Secondary School Mathematics Students' Achievement And Academic Self-Esteem In Fractions". American International Journal of Contemporary Research, vol. 2, no. 2, pp. 141-147, 2015.

[5] F. Razak. "The Effect of Cooperative Learning on Mathematics Learning Outcomes Viewed from Students' Leraning Motivation". Journal of Research and Advances in Mathematics Education, vol. 1, no. 1, pp. 49-55, 2016.

[6] A. D. Susandi, Budiyono, dan D. R. S. Saputro. "Eksperimentasi Model Pembelajaran Kooperatif Tipe Two Stay Two Stray (TSTS) dan Group Investigation (GI) pada Materi Segiempat Ditinjau dari Kecerdasan Matematis Logis Siswa". Jurnal Elektronik Pembelajaran Matematika, vol. 2, no. 8, pp. 828-841, 2014. 